\title{
Penerapan IPTEK melalui Pelatihan Pemanfaatan Limbah Minyak Jelantah sebagai Sabun Cuci Piring pada Masyarakat Kecamatan Teluk Batang
}

\author{
Arie Antasari Kushadiwijayanto', Megasari Juane Sofiana ${ }^{1}$, Ikha Safitri ${ }^{1}$, \\ Apriansyah $^{1}$, Agus Yuliono ${ }^{2}$, Warsidah ${ }^{2}$ \\ ${ }^{1}$ Jurusan Ilmu Kelautan, FMIPA, Universitas Tanjungpura \\ 2 Program Studi Antropologi Sosial, FISIP, Universitas Tanjungpura \\ * Correspondent Author: warsidah@fmipa.untan.ac.id
}

\begin{abstract}
ABSTRAK
Kecamatan Teluk Batang mengalami pertumbuhan penduduk setiap tahunnya, dimana salah satu dari sembilan bahan pokok yang dikonsumsi oleh seluruh lapisan masyarakatnya adalah minyak goreng. Pada umumnya, minyak goreng yang dikonsumsi adalah minyak kelapa yang dapat digunakan sebanyak 1-3 kali penggorengan. Namun, penggunaan secara berulang-ulang akan mengakibatkan perubahan warna dan mengakibatkan asam lemak dalam minyak tersebut menjadi semakin jenuh. Jumlah penduduk yang semakin bertambah, peningkatan kapasitas berbagai industri makanan, restoran, serta usaha kedai fastfood memberikan dampak signifikan terhadap peningkatan jumlah limbah minyak goreng bekas (jelantah). Minyak jelantah dianggap sudah tidak mempunyai nilai ekonomis sehingga sering dibuang langsung ke lingkungan dan tidak diolah kembali. Pemanfaatan minyak jelantah menjadi produk sabun merupakan salah satu cara yang dapat dikembangkan untuk mengurangi limbah rumah tangga. Pelatihan ini bertujuan untuk menerapkan IPTEK dalam pemanfaatan limbah minyak jelantah sebagai sabun cuci piring pada masyarakat Kecamatan Teluk Batang. Pelatihan diawali dengan proses penjernihan sampel minyak jelantah, dilanjutkan dengan proses bleaching, menghilangkan bau (deodorasi) menggunakan karbon aktif, dan proses penyabunan. Untuk memberikan warna dan aroma yang menarik pada produk sabun yang dihasilkan, ditambahkan minyak sereh wangi. Produk sabun cuci piring yang dihasilkan dapat langsung digunakan untuk keperluan pribadi rumah tangga.
\end{abstract}

Kata Kunci: Iptek, Jelantah, Minyak, Sabun

Received: July 8, 2021

Revised: August 10, 2021

Accepted: September 1, 2021

This is an open-acces article distributed under the terms of the Creative Commons Attribution-ShareAlike 4.0 International License.

\section{PENDAHULUAN}

Kecamatan Teluk Batang Kabupaten Kayong Utara memiliki luas wilayah sebesar 213,82 km², terdiri dari 7 Desa dengan total jumlah penduduk mencapai 21.974 jiwa. Masyarakat Kecamatan Teluk Batang memiliki mata pencaharian yang beragam mulai dari bertani, beternak, nelayan, PNS, karyawan swasta, dan wirausaha berbagai industri. Jumlah industri pangan sebanyak 141 unit atau sekitar 62,4\% dari total industri yang ada (BPS Kabupaten Kayong Utara, 2019). Kecamatan Teluk Batang mengalami pertumbuhan penduduk setiap tahunnya. Salah satu dari sembilan bahan pokok yang dikonsumsi oleh seluruh lapisan masyarakat, termasuk Kecamatan Teluk Batang adalah minyak goreng.

Minyak goreng berbentuk cair pada suhu kamar, berasal dari ekstrak lemak tumbuhan (nabati) atau hewan (hewani) yang dimurnikan. Minyak goreng nabati dapat diproduksi dari kelapa, kedelai, jagung, kacang-kacangan, dan biji-bijian. Pada umumnya, minyak goreng yang dikonsumsi keluarga adalah minyak kelapa dan dapat digunakan sebanyak 1-3 kali penggorengan (Kapitan, 2013). Minyak goreng 


\section{Journal of Community Engagement in Health}

http://jceh.org

https://doi.org/10.30994/jceh.v4i2.253

ISSN: 2620-3758 (print); 2620-3766 (online)

Vol. 4 No 2. Sep 2021. Page. 313-318

dari kelapa umumnya mengandung zat warna alamiah seperti $\alpha$ - dan $\beta$-karoten ataupun turunannya. Penggunaan minyak yang berulang kali akan mengakibatkan perubahan warna dari kuning menjadi warna kuning kecokelatan atau cokelat kemerahan. Minyak goreng yang sehat memiliki kandungan asam lemak tak jenuh lebih banyak daripada kandungan asam lemak jenuhnya. Penggunaan minyak goreng berkali-kali akan mengakibatkan asam lemak dalam minyak tersebut menjadi semakin jenuh, sehingga dianggap telah rusak dan tidak layak digunakan untuk menggoreng lagi. Minyak inilah yang disebut sebagai minyak jelantah atau waste cooking oil (Lipoeto, 2011; Alfian et al., 2012). Minyak goreng yang dipanaskan secara berulang-ulang akan menghasilkan senyawa peroksida yang berbahaya bagi tubuh (Thadeus, 2012). Selain itu, tingginya kadar asam lemak jenuh dalam minyak akan menyebabkan makanan yang digoreng juga mengalami peningkatan kadar asam lemak jenuh yang berpotensi membahayakan kesehatan. Efek yang ditimbulkan akan terlihat dalam jangka waktu yang panjang (Asyiah, 2009). Masalah kesehatan yang dapat muncul berupa penimbunan lemak di sekitar hati dan pembuluh darah, kanker, dan kontrol pusat syaraf yang tidak sempurna (Suryandari, 2014).

Jumlah penduduk yang semakin bertambah, peningkatan kapasitas berbagai industri makanan, restoran, serta usaha kedai fastfood memberikan dampak signifikan terhadap peningkatan jumlah limbah minyak goreng bekas (jelantah). Minyak jelantah dianggap sudah tidak mempunyai nilai ekonomis sehingga sering dibuang langsung ke lingkungan dan tidak diolah kembali. Berdasarkan hasil penelitian sebelumnya, minyak jelantah dapat dimurnikan melalui proses reaksi penyabunan menggunakan larutan $\mathrm{KOH}$ (Dalimunthe, 2009) dan digunakan sebagai bahan baku alternatif dalam pembuatan sabun, baik dalam bentuk cair maupun padat (Prihanto dan Irawan, 2018; Lubis dan Mulyati, 2019). Pemanfaatan minyak jelantah menjadi produk sabun (Dhona et al., 2020; Kusuma et al., 2021) merupakan salah satu cara yang dapat dikembangkan untuk mengurangi limbah rumah tangga (Handayani et al., 2021). Oleh karena itu, pelatihan ini bertujuan untuk menerapkan IPTEK dalam pemanfaatan limbah minyak jelantah sebagai sabun cuci piring pada masyarakat Kecamatan Teluk Batang dan mengedukasi masyarakat supaya tidak menggunakan kembali minyak jelantah untuk mengolah makanan karena bahaya terhadap kesehatan.

\section{BAHAN DAN METODE Waktu dan Tempat}

Program PKM dengan judul "Penerapan IPTEK melalui Pelatihan Pemanfaatan Limbah Minyak Jelantah sebagai Sabun Cuci Piring pada Masyarakat Kecamatan Teluk Batang” ini dilaksanakan pada Tanggal 20 Agustus 2021 di Desa Sungai Paduan, Kecamatan Teluk Batang, Kabupaten Kayong Utara, Kalimantan Barat.

\section{Alat dan Bahan}

Alat dan bahan yang digunakan dalam pelatihan pembuatan sabun cuci piring menggunakan limbah minyak jelantah ini adalah mixer, sarung tangan karet, timbangan, botol plastik, spatula, sendok plastik, wadah kaca, wadah plastik, minyak jelantah, $\mathrm{KOH}$ dan aquadest.

\section{Prosedur Pelaksanaan Kegiatan}

Kegiatan PKM ini terdiri dari beberapa tahapan dengan tetap mengikuti protokol kesehatan untuk memutus mata rantai penyebaran Covid-19, yaitu :

1. Pendahuluan

a. koordinasi tim pelaksana kegiatan dengan pemerintah Kecamatan Teluk Batang secara daring untuk menentukan waktu pelaksanaan dan daftar undangan. Dari kesepakatan yang diperoleh, dibuat undangan kepada 30 warga yang mewakili RT masing-masing. Pelaksanaan kegiatan disepakati pada minggu ke-3 bulan Agustus.

b. Tim pelaksana berkoordinasi dengan peserta yang sudah menyatakan kesediaan hadir pada kegiatan tersebut untuk melakukan persiapan alat dan bahan.

c. Pengurusan administrasi perizinan oleh tim kepada Desa Paduan Kecamatan Teluk Batang, serta penentuan dan distribusi undangan.

d. Pemberangkatan Tim pelaksana dari Universitas Tanjungpura ke lokasi kegiatan yang ditempuh selama 4 jam perjalanan menggunakan speedboat. 


\section{Journal of Community Engagement in Health}

http://jceh.org

ISSN: 2620-3758 (print); 2620-3766 (online)

Vol. 4 No 2. Sep 2021. Page. 313-318

\section{Pelaksanaan}

a. Kegiatan diikuti dilaksanakan di ruang pertemuan warga Desa Paduan wilayah Kecamatan Teluk Batang dan dihadiri oleh 15 orang peserta dari 30 undangan yang dikirimkan. Peserta terdiri dari Ibu Rumah Tangga (IRT) dan remaja yang dibagi dalam 3 kelompok.

b. Kegiatan dilakukan dengan metode ceramah ilmiah/edukatif tentang bahaya dari penggunaan minyak jelantah dan pemanfaatannya sebagai bahan dasar alternatif sabun cair serta tahapan proses pembuatan sabun cair cuci piring tersebut.

c. Demonstrasi pembuatan sabun oleh tim pelaksana kegiatan melalui tontonan video yang dilanjutkan dengan praktek pembuatan sabun secara langsung untuk semua peserta,. Selanjutnya, kegiatan dilanjutkan dengan diskusi dan tanya jawab.

3. Evaluasi Kegiatan

Evaluasi dilakukan secara langsung pada akhir kegiatan terkait pengetahuan peserta tentang ceramah edukatif yang telah didengarkan sebelumnya, bahaya penggunaan minyak jelantah yang berulang kali penggorengan, serta menilai mutu produk sabun yang dihasilkan dari masing-masing kelompok.

HASIL

\section{Ceramah}

Kegiatan Pengabdian Kepada Masyarakat (PKM) dilaksanakan sebagai salah satu aktualitasi Tri Dharma Perguruan Tinggi Universitas Tanjungpura, Pontianak, Kalimantan Barat. Kegiatan dilaksanakan secara offline karena berlangsung di luar masa PPKM (Pemberlakuan Pembatasan Kegiatan Masyarakat), dengan tetap mensyaratkan kepada semua peserta dan tim pelaksana untuk melaksanakan protokol kesehatan yang ketat. Sebelum peserta dan tim pelaksana memasuki ruang kegiatan, Mencuci tangan, Memakai masker dan Menjaga jarak (3M) adalah proteksi tingkat pertama sebagai usaha dalam memutus mata rantai penyebaran Covid-19. Selain itu, tim pelaksana dan peserta kegiatan juga telah memiliki kartu vaksin Covid-19, sehingga dapat mengurangi kekhawatiran terkait dengan penularan virus.

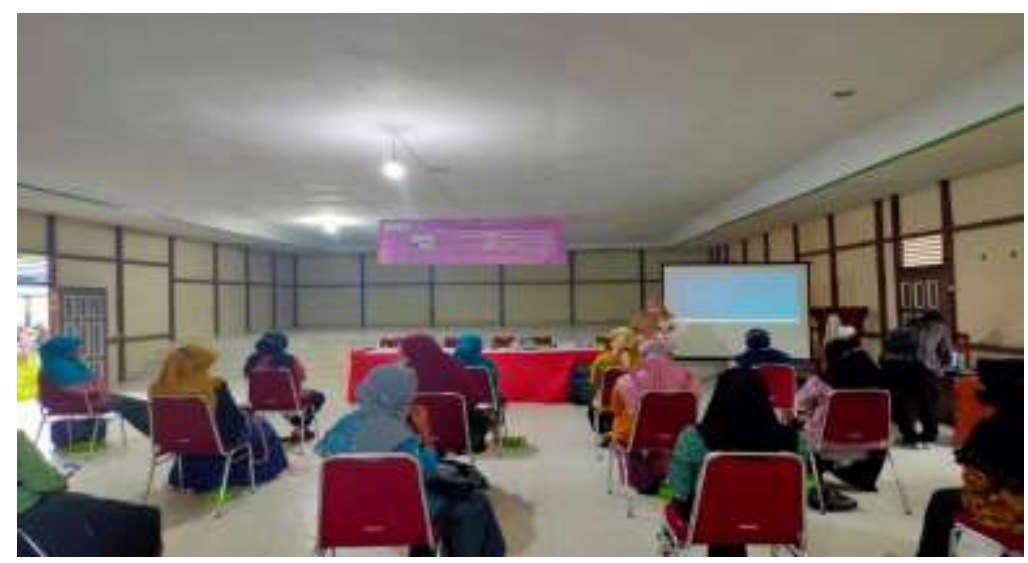

Gambar 1. Ceramah ilmiah tentang bahaya penggunaan minyak jelantah dan pemanfaatannya sebagai bahan dasar alternatif sabun cair

Seluruh peserta kegiatan sangat antusias mengikuti pelatihan pembuatan sabun cuci piring menggunakan minyak jelantah. Sebelum mulai membuat sabun, tim pelaksana kegiatan dari Universitas Tanjungpura yang merupakan dosen berbagai Program Studi terlebih dahulu memberikan ceramah ilmiah tentang bahaya penggunaan minyak jelantah dan pemanfaatannya sebagai bahan dasar alternatif sabun cair.

\section{Pembuatan Sabun Cuci Piring}

Kegiatan pelatihan pembuatan sabun cair diawali dengan proses penjernihan sampel minyak jelantah. Sebanyak 100 gram minyak jelantah dimasukkan ke dalam wadah kemudian disaring untuk memisahkan dari kotoran. Tahapan berikutnya adalah proses bleaching dan menghilangkan bau (deodorasi) dengan menggunakan karbon aktif (Yustinah dan Hartini, 2011) hingga bau minyak jelantah hilang dan tidak tercium lagi. Langkah selanjutnya merupakan tahapan utama dalam proses pembuatan 


\section{Journal of Community Engagement in Health}

http://jceh.org

https://doi.org/10.30994/jceh.v4i2.253

ISSN: 2620-3758 (print); 2620-3766 (online)

Vol. 4 No 2. Sep 2021. Page. 313-318

sabun cuci piring yang diawali dengan pembuatan larutan $\mathrm{KOH} 30 \%$ dengan cara melarutkan 30 gram $\mathrm{KOH}$ ke dalam $100 \mathrm{~mL}$ aquadest. Proses penyabunan selanjutnya dilakukan dengan cara memanaskan minyak jelantah murni pada suhu antara $45-55^{\circ} \mathrm{C}$ dan ditambahkan larutan $\mathrm{KOH}$ dengan perbandingan 100 g minyak : $50 \mathrm{~mL} \mathrm{KOH} \mathrm{30 \% .} \mathrm{Kemudian,} \mathrm{campuran} \mathrm{diaduk} \mathrm{dengan} \mathrm{mixer} \mathrm{selama} 45$ menit. Untuk memberikan warna dan aroma yang menarik pada produk sabun yang dihasilkan, ditambahkan minyak sereh wangi.
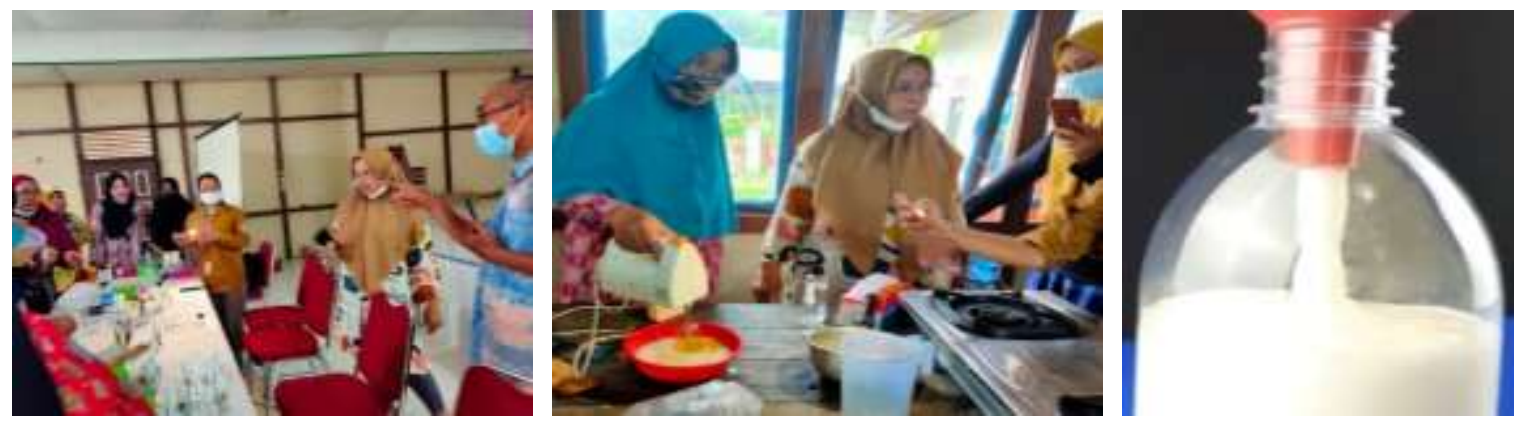

Gambar 2. Proses pembuatan sabun cuci piring menggunakan limbah minyak jelantah

\section{PEMBAHASAN}

Minyak goreng adalah salah satu kebutuhan pokok dalam sebuah keluarga, yang pada umumnya berupa minyak nabati. Komponen utama adalah gliserida dari turunan asam lemak yang ada di dalamnya. Minyak mengalami proses pemanasan pada suhu antara $160-250{ }^{\circ} \mathrm{C}$ pada saat digunakan untuk menggoreng. Berdasarkan komposisi kimia, minyak jelantah pada umumnya mengandung senyawa karsinogenik yang terbentuk selama proses penggorengan (Yusuf, 2010). Senyawa ini berpotensi menimbulkan kanker serta penyakit lain yang berbahaya bagi kesehatan tubuh manusia. Setelah terpapar suhu panas, minyak akan rusak dan menimbulkan bau tengik, berubah menjadi kental, berbusa (Susinggih et al., 2005), serta kandungan Free Fatty Acid (FFA) akan semakin meningkat (Aminah, 2010). Minyak bekas penggorengan ini dinamakan minyak jelantah (Tomskaya et al., 2008; Hajar dan Mufidah, 2016).

Minyak dan lemak merupakan kebutuhan utama dalam industri teknologi pengolahan pangan. Keduanya memiliki titik didih tinggi $\pm 200^{\circ} \mathrm{C}$ sehingga bahan pangan yang digoreng akan menghasilkan makanan dengan kadar air yang rendah. Selain itu, minyak juga dapat memberikan efek gurih dan aroma makanan menjadi lebih spesifik (Putra et al., 2012). Produksi minyak jelantah yang mengandung asam lemak jenuh akan semakin meningkat seiring dengan pertumbuhan industri makanan yang ada di Kecamatan Teluk Batang. Minyak goreng merupakan kebutuhan utama jalannya produksi tersebut. Namun, selama ini masyarakat sering membuang minyak jelantah tersebut karena dianggap tidak memiliki nilai ekonomis. Limbah minyak jelantah yang dibuang langsung ke lingkungan dapat menimbulkan pencemaran. Padahal, limbah minyak jelantah tersebut masih dapat dimanfaatkan melalui proses pemurnian (Hajar dan Mufidah, 2016). Hal ini karena minyak jelantah masih mengandung komponen asam lemak jenuh dan tak jenuh seperti asam oleat dan asam linoleat dalam jumlah yang sangat sedikit. Oleh karena itu, minyak jelantah dapat dimanfaatkan untuk menghasilkan produk lain seperti sabun mandi, handsoap, maupun sabun cuci piring yang juga merupakan kebutuhan utama dalam keluarga.

Pemanfaatan limbah minyak jelantah yang telah dimurnikan untuk beberapa produk keterampilan, dapat mengurangi bau yang tidak enak, warna yang tidak menarik dan larutan minyak yang mengandung banyak partikel halus dan kasar sehingga penampakan minyak kelihatan kotor (Naomi et al., 2013). Pemanfaatan tersebut juga dapat mengurangi resiko pencemaran terhadap lingkungan, serta mengurangi tingkat kesuburan tanah (Etriya et al., 2004). Selain itu, pengolahan limbah menjadi produk bernilai tambah (added value) juga dapat mencegah kecurangan yang dilakukan oleh oknum pengepul minyak jelantah. Oleh mereka, minyak jelantah dapat diolah kembali melalui proses bleaching dan pewarnaan sehingga menghasilkan minyak seperti barang baru. Padahal, minyak tersebut tetap mengandung senyawa yang berpotensi menyebabkan kanker. 


\section{Journal of Community Engagement in Health}

http://jceh.org

https://doi.org/10.30994/jceh.v4i2.253

ISSN: 2620-3758 (print); 2620-3766 (online)

Vol. 4 No 2. Sep 2021. Page. 313-318

Sabun dari limbah minyak jelantah yang dimurnikan dapat digunakan untuk mencuci atau membersihkan noda jika digosokkan pada permukaan bahan. Sabun dihasilkan dari proses hidrolisis minyak menjadi asam lemak bebas dan gliserol yang dilanjutkan dengan proses saponifikasi dalam suasana alkali (Hajar et al., 2016). Garam dari alkali asam lemak merupakan sabun dari reaksi saponifikasi dengan cara memanaskan lemak dan Kalium Hidroksida $(\mathrm{KOH})$ atau Natrium Hidroksida $(\mathrm{NaOH})$ sampai terhidrolisis sempurna. Saponifikasi dalam suasana alkali dengan penambahan $\mathrm{NaOH}$ menghasilkan sabun padat (Lubis dan Mulyati, 2019), sedangkan dalam penambahan alkali Kalium Hidroksida (KOH) akan menghasilkan sabun lunak atau sabun cair (Wijana et al., 2009; Naomi et al., 2013; Pratiwi, 2014).

Pelatihan pembuatan sabun berbasis limbah minyak jelantah ini dapat meningkatkan pengetahuan dan kemampuan masyarakat dalam memanfaatkan sumberdaya termasuk memanfaatkan limbah yang dapat merusak lingkungan. Seluruh peserta yang hadir sangat antusias dan memperlihatkan semangat berkarya dalam menyelesaikan proses demi proses pembuatan sabun dari limbah minyak jelantah. Tahap akhir dari kegiatan ini adalah evaluasi mulai dari kegiatan dimulai hingga produk sabun cair dihasilkan. Peserta kegiatan menunjukkan antusiasme dan memberikan jawaban-jawaban yang benar pada saat sesi tanya jawab berlangsung. Selain itu produk sabun yang dihasilkan sudah bebas dari aroma minyak jelantah serta berwarna cerah. Hal ini karena minyak telah terabsorpsi saat penambahan arang aktif, serta adanya penambahan aroma minyak sereh wangi dan pewarna kuning terang pada saat produksi.

\section{KESIMPULAN}

Berdasarkan hasil kegiatan pelatihan pembuatan sabun cuci piring dari limbah minyak jelantah dapat disimpulkan :

1. Masyarakat Kecamatan Teluk Batang telah memahami bahwa penggunaan kembali minyak jelantah untuk mengolah makanan dapat menyebabkan gangguan kesehatan karena terbentuknya zat karsinogenik selama pemanasan.

2. Masyarakat Kecamatan Teluk Batang dapat memahami tentang pembuatan sabun berbasis limbah minyak jelantah.

3. Masyarakat Kecamatan Teluk Batang sudah mampu membuat sabun cuci piring sederhana dari limbah minyak jelantah yang dimurnikan untuk keperluan pribadi rumah tangga.

\section{UCAPAN TERIMAKASIH}

Penulis menyampaikan terimakasih kepada Badan Restorasi Gambut dan Mangrove yang telah memfasilitasi secara material dan administrasi pelaksanaan kegiatan pelatihan ini.

\section{REFERENSI}

Aisyah, N. 2009. Pemanfaatan Minyak Goreng Bekas menjadi Sabun Mandi Padat. Pasca Sarjana Teknik Kimia. Universitas Sumatera Utara. Medan.

Alfian, P., Mardhania, S., Septia, E., Dewi, A. 2012. Recovery Minyak Jelantah Menggunakan Mengkudu Sebagai Absorben. Prosiding Seminar Nasional PERTETA.

Aminah, S. 2010. Bilangan Peroksida Minyak Goreng Curah dan Sifat Organoleptik Tempe pada Pengulangan Penggorengan. Jurnal Pangan dan Gizi, 1(1): 115523. https://doi.org/10.26714/jpg.1.1.2010.

Badan Pusat Statistik Kabupaten Kayong Utara. 2019. Kecamatan Teluk Batang dalam Angka 2019.

Dalimunthe, N.S. 2009. Pemanfaatan Minyak Goreng Bekas menjadi Sabun Mandi Padat. [Tesis]. Jurusan Teknik Kimia, Universitas Sumatera Utara.

Dhona, W., Desianasari, D.N., Harling, W.A.S., Wirantika, T.A., Santoso, W. 2020. Pelatihan Pembuatan Sabun Cuci Piring dari Minyak Jelantah sebagai Upaya Pemanfaatan Limbah Rumah Tangga. KKN BMC, Universitas Negeri Semarang.

Etriya, Sumarwan, U., Kirbrandoko. 2004. Analisis Ekuitas Berbagai Merek Minyak Goreng. Jurnal Manajemen \& Agribisnis, 1(2): 127-139.

Hajar, E. W. I., Purba, A. F. W., Handayani, P., Mardiah. 2016. Proses Pemurnian Minyak Jelantah Menggunakan Ampas Tebu Untuk Pembuatan Sabun Padat. Jurnal Integrasi Proses, 6(2): 57-63. 


\section{Journal of Community Engagement in Health}

http://jceh.org

https://doi.org/10.30994/jceh.v4i2.253

ISSN: 2620-3758 (print); 2620-3766 (online)

Vol. 4 No 2. Sep 2021. Page. 313-318

Hajar, E. W. I, dan Mufidah, S. 2016. Penurunan Asam Lemak Bebas pada Minyak Goreng Bekas Menggunakan Ampas Tebu untuk Pembuatan Sabun. Jurnal Integrasi Proses, 6(1): 22-27.

Handayani, K., Kanedi, M., Farisi, S., Setiawan, W.A. 2021. Pembuatan Sabun Cuci dari Minyak Jelantah sebagai Upaya Mengurangi Limbah Rumah Tangga. Jurnal Pengabdian Kepada Masyarakat Tabikpun, 2(1): 55-62.

Kapitan, B.O. 2013. Analisis Kandungan Asam Lemak Trans (Trans Fat) dalam Minyak Bekas Penggorengan Jajanan di Pinggir Jalan Kota Kupang. Jurnal Kimia Terapan, 1(1): 17-31.

Kusuma, A.A. 2021. Pengurangan Limbah Minyak Jelantah dengan Pelatihan Pembuatan Sabun Cuci Cair Ekonomis di Kampung Sawah, Bogor. Patria : Jurnal Pengabdian Kepada Masyarakat, 3(1): 68-78.

Lipoeto, E. 2011. Synthesis of Biodiesel via Acid Catalysis. Ind. Eng. Chem. Research, 44(14): $5353-$ 5363.

Lubis, J., dan Mulyati, M. 2019. Pemanfaatan Minyak Jelantah Menjadi Sabun Padat. Jurnal Metris, 20(2): 116-120.

Naomi, P., Lumban Gaol, A. M., Toha, M. Y. 2013. Pembuatan Sabun Lunak dari Minyak Goreng Bekas Ditinjau dari Kinetika Reaksi Kimia. Jurnal Teknik Kimia, 19(2): 42-48.

Pratiwi, P. 2014. Pembuatan Sabun Cuci Piring Cair dari Minyak Goreng Bekas (Jelantah). Universitas Sebelas Maret.

Prihanto, A. dan Irawan, B. 2018. Pemanfaatan Minyak Goreng Bekas Menjadi Sabun Mandi. Metana: Media Komunikasi Rekayasa Proses dan Teknologi Tepat Guna, 14(2): 55-59.

Putra, A., Mahrdania, S., Dewi, A., Saptia, E. 2012. Recovery Minyak Jelantah Menggunakan Mengkudu sebagai Absorben. Prosiding Seminar Nasional PERTETA. Malang, Jawa Timur: PerhimpunanTeknik Pertanian Indonesia (PERTETA), pp. 585-589.

Suryandari, E. T. 2014. Pelatihan Pemurnian Minyak Jelantah dengan Kulit Pisang Kepok (Musa paradisiaca, Linn) untuk Pedagang Makanan di Pujasera Ngaliyan. Dimas: Jurnal Pemikiran Agama untuk Pemberdayaan, 14(1): 57-70.

Susinggih, W. 2005. Mengolah Minyak Goreng Bekas. Trubus Agrisarana, Surabaya.

Thadeus, M. S. 2012. Dampak Konsumsi Minyak Jelantah terhadap Kerusakan Oksdatif DNA (Disertasi). Program Doktor Ilmu Kedokteran dan Kesehatan, Universitas Gadjah Mada. Yogyakarta.

Tomskaya, L. A., Makarova, N. P., Ryabov, V. D. 2008. Determination of the hydrocarbon composition of crude oils. Chemistry and Technology of Fuels and Oils, 44(4): 280-283.

Wijana, S., Soemarjo, Harnawi, T. 2009. Studi Pembuatan Sabun Mandi Cair dari Daur Ulang Minyak Goreng. Jurnal Teknologi Pertanian, 10(1): 54-61.

Yustinah dan Hartini. 2011. Adsorbsi Minyak Goreng Bekas menggunakan Arang Aktif dari Sabut Kelapa. Prosiding Seminar Nasional Teknik Kimia “Kejuangan”, Yogyakarta.

Yusuf, Y. 2010. Penyuluhan dan Pelatihan Pemanfaatan Limbah Minyak Goreng (Minyak Jelantah) sebagai Bahan Baku Pembuatan Sabun Cair. Warta Pengabdian Andalas, 1: 195-206. 